\title{
Diet matters, particularly in pregnancy - Results from MoBa studies of maternal diet and pregnancy outcomes
}

\author{
Anne Lise Brantsæter ${ }^{1 \S}$, Margaretha Haugen ${ }^{1}$, Ronny Myhre $^{2}$, Verena Sengpiel ${ }^{3}$, Linda Englund-Ögge ${ }^{3}$, \\ Roy Miodini Nilsen ${ }^{4}$, Iren Borgen ${ }^{5}$, Talita Duarte-Salles ${ }^{6}$, Eleni Papadopoulou ${ }^{1}$, Kristine Vejrup ${ }^{2}$, \\ Anne von Ruesten ${ }^{7}$, Elisabet Rudjord Hillesund ${ }^{8}$, Bryndis Eva Birgisdottir ${ }^{1,9}$, Per Magnus ${ }^{2}$, \\ Lill Trogstad ${ }^{2}$, Bo Jacobsson ${ }^{2,3}$, Jonas Bacelis ${ }^{3,10}$, Solveig Myking ${ }^{2}$, Helle K. Knutsen ${ }^{1}$, \\ Helen E. Kvalem ${ }^{1}$, Jan Alexander ${ }^{11}$, Michelle Mendez ${ }^{12}$ and Helle Margrete Meltzer ${ }^{1}$ \\ ${ }^{I}$ Division of Environmental Medicine, Norwegian Institute of Public Health, N-0403 Oslo, Norway \\ ${ }^{2}$ Division of Epidemiology, Norwegian Institute of Public Health, Oslo, Norway \\ ${ }^{3}$ Department of Obstetrics and Gynecology, Sahlgrenska Academy, Sahlgrenska University Hospital, Gothenburg, Sweden \\ ${ }^{4}$ Department of Global Public Health and Primary Care, University of Bergen, Bergen, Norway \\ ${ }^{5}$ Oslo University Hospital, Oslo, Norway \\ ${ }^{6}$ International Agency for Research on Cancer (IARC-WHO), Lyon, France \\ ${ }^{7}$ Department of Public Health and Community Medicine, University of Gothenburg, Gothenburg, Sweden \\ ${ }^{8}$ Department of Public Health, Sports and Nutrition, University of Agder, Kristiansand, Norway \\ ${ }^{9}$ Unit for Nutrition Research, National University Hospital, Faculty of Food Science and Nutrition, University of Iceland, \\ Reykjavik, Iceland \\ ${ }^{10}$ Institute of Clinical Sciences, Sahlgrenska Academy, University of Gothenburg, SE-40530, Gothenburg, Sweden \\ ${ }^{11}$ Office of the Director-General, Norwegian Institute of Public Health, Oslo, Norway \\ ${ }^{12}$ Department of Nutrition, Gillings School of Global Public Health, University of North Carolina at Chapel Hill, \\ Chapel Hill, USA \\ ${ }^{\S}$ Correspondence: Anne Lise Brantsæter, Department of Exposure and Risk Assessment, Division of Environmental Medicine, \\ Norwegian Institute of Public Health, P.O. Box 4404 Nydalen, NO-0403 Oslo, Norway \\ E-mail: AnneLise.Brantsaeter@fhi.noＴelephone: +47 21076326
}

\begin{abstract}
Awareness that maternal diet may influence the outcome of pregnancy as well as the long-term health of mother and child has increased in recent years. A new food frequency questionnaire (FFQ) was developed and validated specifically for the Norwegian Mother and Child Cohort Study (MoBa). The MoBa FFQ is a semi-quantitative tool which covers the average intake of food, beverages and dietary supplements during the first 4 to 5 months of pregnancy. It includes questions about intakes of 255 foods and dishes and was used from 2002 onwards. Data assessed by the MoBa FFQ is available for 87,700 pregnancies. Numerous sub-studies have examined associations between dietary factors and health outcomes in MoBa. The aim of this paper is to summarize the results from 19 studies of maternal diet and pregnancy outcomes, which is the complete collection of studies based on the MoBa FFQ and published before September 2014. The overall research question is whether maternal diet - from single substances to dietary patterns - matters for pregnancy outcome. The pregnancy outcomes studied till now include birth size measures, infants being small and large for gestational age, pregnancy duration, preterm delivery, preeclampsia, as well as maternal gestational weight gain and postpartum weight retention. As a whole, the results from these studies corroborate that the current dietary recommendations to pregnant women are sound and that maternal diet during pregnancy is likely to contribute to reduce the risk of pregnancy complications including preterm birth, preeclampsia, and reduced foetal growth. The results provide supporting evidence for recommending pregnant women to consume vegetables, fruit, whole grain, fish, dairy, and water regularly and lower the intake of sugar sweetened beverages, processed meat products and salty snacks. The results showing negative impact of even low levels of environmental contaminants support the precautionary advice on consumption of foods containing these. New findings are that particularly lean fish explained the positive association between seafood intake and foetal growth, and the indications of a protective effect of probiotic and antimicrobial foods on pregnancy outcomes. This points to the importance of diet composition for a healthy gut flora and the body's immune response. Although these studies are observational and cannot infer causality, the results identify diet as an important modifiable lifestyle factor, suggesting that healthy eating, defined as following the official recommendations, is particularly important in pregnancy.
\end{abstract}

This is an open access article distributed under the Creative Commons Attribution Licence, which permits unrestricted use, distribution, and reproduction in any medium, provided the original work is properly cited.

\section{INTRODUCTION}

Diet impacts all systems of the body, including the foetus, and can modulate different functions far beyond the levels that are connected to malnutrition, e.g. expression of genes, hormone levels, inflammation and the nervous system $(1,2)$. During the last decades there has been increased understanding that the maternal diet directly affects the growing foetus and influences health risks later in life (3-6). This also includes food- 
borne harmful components, e.g. environmental contaminants, to which the foetus may be particularly susceptible $(7,8)$. Consequently, monitoring of dietary intake has become an integral part of pregnancy and birth cohort studies.

The Norwegian Mother and Child Cohort Study (MoBa) is a prospective population-based pregnancy cohort study conducted by the Norwegian Institute of Public Health. Participants were recruited from all over Norway from 1999-2008. The women consented to participation in $40.6 \%$ of the pregnancies. The cohort includes 114,500 children, 95,200 mothers and 75,200 fathers. The basic planning of MoBa was not made on the basis of any single hypothesis or even any set of hypotheses; the strategy was to collect data on as many relevant exposures and health outcomes as feasible (9). With regard to diet, this implied to cover as many aspects of the diet as possible. We were given the opportunity to develop and validate a food frequency questionnaire (FFQ) tailored for the MoBa study and to be answered during pregnancy. The response rate for the FFQ was $90.4 \%$.

The relationship between diet and health can be examined at the level of single substances e.g. nutrients or contaminants, at the level of foods or food groups, e.g. fish and milk products, or by exploring dietary patterns. The analysis of dietary patterns provides a broader view of dietary behaviour than analyses of single foods and substances by taking into account that foods and nutrients are consumed in combinations (10). Dietary patterns can be extracted based on a-priori definitions, e.g. scores on a healthy eating index, or by data-driven techniques that groups together correlated food variables and thereby identifies underlying patterns in the data (11).

The MoBa FFQ has so far been used to study maternal diet in more than fifty scientific publications, some descriptive (e.g. 12-14), some testing hypotheses related to pregnancy outcomes (15-33), some testing hypotheses related to later health outcomes in mothers and children (e.g. 34-37), and some in which dietary factors were included as predictors or confounding variables (e.g. 38-42). The aim of the present study is to summarize the complete collection of studies in MoBa published before September 2014 which examined maternal diet (based on the MoBa FFQ) and pregnancy outcomes, focusing on foetal growth measures, preeclampsia, preterm delivery, gestational weight gain and maternal weight retention. The overall research question is whether maternal diet - from single substances to dietary patterns - matters for pregnancy outcomes and whether new knowledge has emerged from these dietary studies in MoBa.

\section{METHODS}

The MoBa FFQ (downloadable from www.fhi.no/ dokumenter/011fbd699d.pdf) is a semi-quantitative questionnaire and was designed to capture dietary habits and intake of dietary supplements during the first
4-5 months of pregnancy. It asked women at gestational week 17-22 about their average intake of 255 food items, including food items known to contribute to exposure to environmental contaminants, e.g. rare food items such as fish liver and seagull eggs. The methodological challenges when developing the MoBa FFQ have been described in detail (43). The questionnaires were optically read and food frequencies were converted into food and nutrient intakes using FoodCalc (44) and the Norwegian food composition table (45). We established a database for the amount of nutrients contributed by dietary supplements and databases for food concentrations of substances not included in the national food table, e.g. dioxins and polychlorinated biphenyls (PCBs), mercury, acrylamide, benzo(a)pyrene (B(a)P), and caffeine. Parallel to the implementation of the FFQ in March 2002, a validation study was carried out in $119 \mathrm{MoBa}$ participants using a 4 day weighed food diary and biological markers of intake as reference measures. The validation study showed that the FFQ enables reasonable ranking of the participants' diet according to major food groups and nutrients (46$49)$ as well as nutrient intakes through dietary supplements (50).

In the studies summarized in this paper, some identified dietary patterns based on á priori definitions, and some by principal component analysis. Statistical modelling of associations between dietary exposures and pregnancy outcomes have been conducted using linear and logistic bivariate and multinomial regression models, making it possible to take into account a number of known risk factors and potential confounding factors. Most outcomes, e.g. preeclampsia and preterm delivery, are relatively rare so that odds ratios (OR) were interpreted as relative risks. For studying preterm delivery we also used hazard ratios (HR) with gestational length as the time to event. All risk estimates reported in the results sections below are multivariate adjusted estimates. Participant numbers in the substudies differ because updated versions of the datafiles were released and because study-specific inclusion and exclusion criteria were defined. The discussion of adjustment variables in each of the studies was considered beyond the scope of this paper.

\section{RESUlts}

This paper summarizes the results from 19 studies of maternal diet and pregnancy outcomes in MoBa. The results have been organized by pregnancy outcome. Studies that examined more than one pregnancy outcome are summarized with regard to all relevant outcomes.

\section{Maternal diet and infant size at birth}

Birth weight is considered a marker of intrauterine development and is a strong predictor of infant survival and an indicator of health status later in life $(51,52)$. Birth weight is strongly dependent of gestational length, and the outcomes "small for gestational age (SGA)" and "large for gestational age" (LGA) refer to 
infants whose size and weight is less than or above the average range for infants of the same gestational age. Both SGA and LGA children are at greater risk of developing type 2 diabetes and cardiovascular disease later in life (53). Eight studies have investigated maternal dietary factors in relation to infant birth size (Summary Table 1).

No statistically significant associations were found for maternal intake of folate from food, folic acid from dietary supplements or maternal plasma folate concentration with infant birth weight, length, head circumference, or risk of SGA defined as infant birth weight below the 10th percentile within strata of infant gender and gestational age using national reference data. The study sample comprised 2,936 mothers who delivered singleton babies (15).

Calculated total maternal caffeine intake as well as caffeine intake from individual sources were consistently associated with lower birth weight and increased risk of SGA. The study sample included 59,123 healthy mothers who delivered singleton live babies. Caffeine intake was assessed by the FFQ as well as by the questionnaires answered in early and late pregnancy. There was no major difference regarding the association for caffeine intake during different periods of pregnancy. The association between caffeine and lower birth weight was strengthened by concordant results for caffeine sources, time of survey and different SGA definitions (16). The results did not indicate any threshold for an effect of caffeine on birth weight or SGA. For intakes of 200-300 mg caffeine/day compared with 0-50 mg/day, total caffeine was associated with 8 to $21 \mathrm{~g}$ lower expected birth weight and increased risk of SGA ranging from 30 to $60 \%$ (ORs ranging from 1.3 to 1.6), depending on choice of growth curve (16).

Maternal seafood intake was positively associated with birth weight and head circumference. Lean fish was positively associated with all birth size measures; shellfish was positively associated with birth weight, while fatty fish was not associated with any birth size measures (17). The study sample comprised 62,099 mothers who delivered singleton live babies. Intake of supplementary $n-3$ was not associated with birth weight and was negatively associated with head circumference. The relative risk of giving birth to a small baby $(<2500 \mathrm{~g})$ in full term pregnancies was significantly lower in women who consumed $>60 \mathrm{~g}$ seafood per day (corresponding to 3 or more servings per week) than in women who rarely consumed (0-5 g/day) seafood; OR=0.56 (95\% CI: $0.35,0.88)$. However, seafood consumption did not increase the risk of giving birth to a large baby $(>4500 \mathrm{~g})(17)$.

Calculated maternal mercury $(\mathrm{Hg})$ exposure was negatively associated with infant birth weight. The study sample comprised 62,941 mothers with singleton term deliveries. Women in the highest quintile compared with the lowest quintile of $\mathrm{Hg}$ exposure delivered babies with an average reduction in birth weight of 34 g (95\% CI: -46, -22) and a significantly increased risk of SGA $(\mathrm{OR}=1.19,95 \% \mathrm{CI}: 1.08,1.30)$. Although the overall seafood intake was associated with increased birth weight (increasing birth weight with increasing quartiles of seafood), stratified analyses showed negative associations between $\mathrm{Hg}$ exposure and birth weight within each strata of seafood intake (18).

As a follow up of a study (54) that showed a negative association between a biological marker of acrylamide exposure and foetal growth (women from five European cohorts, including MoBa, total $n=1,101$ ), the association between calculated dietary acrylamide intake and foetal growth was examined in 50,561 women in MoBa. Calculated acrylamide intake showed strong correlation with haemoglobin- and glycidamide $\mathrm{Hb}$-adducts in a subset of the participating women. Higher maternal acrylamide intake during pregnancy was associated with impaired foetal growth based on an increase in SGA risk and reduction in birth weight (19). Birth weight of children born to women in the highest quartile of acrylamide intake were on average 26 g lower $(95 \% \mathrm{CI}:-36,-15)$ than for children born to women in the lowest quartile of acrylamide intake.

In the same study population (50,561 women), dietary benzo(a)pyrene $[\mathrm{B}(\mathrm{a}) \mathrm{P}]$ intakes were estimated based on a database containing published values of $\mathrm{B}(\mathrm{a}) \mathrm{P}$ concentration in food (20). Dietary B(a)P intake during pregnancy was significantly associated with lower weight and length at birth; coefficients $(95 \% \mathrm{CI})$ were $-20.5 \mathrm{~g}(-31.1,-10.0)$ and $-0.09 \mathrm{~cm}(-0.15,-0.04)$ for tertile 3 vs. tertile 1 . Results were similar after excluding smokers. Significant interactions between dietary $\mathrm{B}(\mathrm{a}) \mathrm{P}$ and vitamin $\mathrm{C}$ equal or above the recommended intake for pregnant women in Norway $(85$ $\mathrm{mg} /$ day) were found ( $p$-value for interaction $=0.022$ ) The coefficients $(95 \% \mathrm{CI})$ for birth weight in women in the third compared with the first tertile of $\mathrm{B}(\mathrm{a}) \mathrm{P}$ intake were $-44.4 \mathrm{~g}(-76.5,-12.3)$ in the group with low vs. $-17.6 \mathrm{~g}(-29.0,-6.1)$ in the group with high vitamin $\mathrm{C}$ intake (20).

Again in the same population (50,561 women), maternal intakes of dioxins and polychlorinated biphenyls (PCBs) were calculated based on an extensive database of these persistent environmental pollutants. Seafood is the major source of exposure to such contaminants. This study showed an inverse dose-response association between dietary intake of dioxins and PCBs and foetal growth. Infants of mothers in the upper quartile of dioxin and dioxin-like PCBs intake had $62 \mathrm{~g}$ lower birth weight (95\% CI: $-73,-50), 0.26 \mathrm{~cm}$ shorter birth length (95\% CI: $-0.31,-0.20)$ and $0.10 \mathrm{~cm}$ smaller head circumference $(95 \% \mathrm{CI}:-0.14,-0.06)$ than those of mothers in the lowest quartile of intake. Similar negative associations for intake of dioxins and dioxinslike PCBs were found after excluding women with intakes above the tolerable weekly intake of $14 \mathrm{pg}$ toxic equivalents (TEQ) per kg body weight per week. The negative association between dietary dioxins and PCBs with foetal growth became weaker as seafood intake increased. No association was found between 
Summary Table 1. Studies investigating maternal dietary factors and infant birth size in the Norwegian Mother and Child Cohort Study.

\begin{tabular}{|c|c|c|c|c|c|}
\hline Reference & $\begin{array}{l}\text { Study } \\
\text { population }\end{array}$ & Dietary exposure & Exposure variables & Studied health outcome & Results \\
\hline $\begin{array}{l}\text { Nilsen et al., } \\
2010(15)\end{array}$ & $\begin{array}{l}2934 \text { women } \\
\text { with singleton } \\
\text { deliveries }\end{array}$ & $\begin{array}{l}\text { Folate contributed by } \\
\text { food and from dietary } \\
\text { supplements. Mean } \\
\text { intake of food folate } \\
\text { and supplemental folic } \\
\text { acid was } 268 \text { and } 188 \\
\mu \mathrm{g} / \text { day }\end{array}$ & $\begin{array}{l}\text { Folate from food, } \\
\text { supplements and total, } \\
\text { divided into }<25^{\text {th }} \\
25-74^{\text {th }}, \geq 75^{\text {th }} \text { percentile }\end{array}$ & $\begin{array}{l}\text { Infant birth weight, } \\
\text { crown-heel length, head } \\
\text { circumference, and SGA } \\
\text { (defined as below the } 10^{\text {th }} \\
\text { percentile population } \\
\text { growth curve) }\end{array}$ & $\begin{array}{l}\text { No associations between maternal } \\
\text { folate intake or maternal plasma } \\
\text { folate concentration and infant birth } \\
\text { weight, length, head circumference } \\
\text { or risk of SGA. }\end{array}$ \\
\hline $\begin{array}{l}\text { Sengpiel } \\
\text { et al., } 2013 \\
\text { (16) }\end{array}$ & $\begin{array}{l}59,123 \text { women } \\
\text { with singleton, } \\
\text { uncomplicated } \\
\text { deliveries }\end{array}$ & $\begin{array}{l}\text { Total caffeine and caf- } \\
\text { feine from individual } \\
\text { sources based on the } \\
\text { FFQ, and caffeine in- } \\
\text { take prior to pregnancy, } \\
\text { in } 1^{\text {st }} \text { and } 3^{\text {rd }} \text { trimester }\end{array}$ & $\begin{array}{l}\text { Caffeine, total and from } \\
\text { different sources as } \\
\text { continuous variables } \\
\text { and total caffeine } \\
\text { ranked into sixtiles, and } \\
\text { divided into categories } \\
\text { representing } 0-50,51- \\
200,201-300 \text { and }>300 \\
\text { mg/day }\end{array}$ & $\begin{array}{l}\text { Infant birth weight and } \\
\text { SGA (defined according } \\
\text { to ultrasound-based, } \\
\text { population-based and } \\
\text { customized growth } \\
\text { curves) }\end{array}$ & $\begin{array}{l}\text { For intakes } 200-300 \mathrm{mg} / \text { day } \\
\text { compared with } 0-50 \mathrm{mg} / \text { day, total } \\
\text { caffeine was associated with lower } \\
\text { expected birth weight ( } 21 \text { to } 8 \mathrm{~g} \text { ) } \\
\text { and increased risk of SGA (adjusted } \\
\text { ORs ranging from } 1.3 \text { to } 1.6) \text {. }\end{array}$ \\
\hline $\begin{array}{l}\text { Brantsæter } \\
\text { et al., } 2012 \\
(17)\end{array}$ & $\begin{array}{l}62,099 \text { women } \\
\text { with singleton, } \\
\text { live deliveries }\end{array}$ & $\begin{array}{l}\text { Intake of total seafood } \\
\text { and supplementary } \\
\text { marine } n-3 \text { fatty acids. } \\
\text { Seafood also examined } \\
\text { by subcategories of lean } \\
\text { fish, fatty fish, shellfish } \\
\text { and fish liver }\end{array}$ & $\begin{array}{l}\text { Continuous seafood } \\
\text { intake (g/day) and by } \\
\text { categories of } 0-5,6-20, \\
21-40,41-60 \text { and } \geq 60 \\
\text { g/day. Supplementary } \\
n-3 \text { fatty acids catego- } \\
\text { rized as none, }<\text { median } \\
\text { and } \geq \text { median }\end{array}$ & $\begin{array}{l}\text { Infant birth weight, } \\
\text { crown-heel length, head } \\
\text { circumference, and risk } \\
\text { of low birth weight } \\
(<2500 \mathrm{~g})\end{array}$ & $\begin{array}{l}\text { Total seafood intake and particularly } \\
\text { lean fish and shellfish was } \\
\text { associated with increased birth } \\
\text { weight, and reduced risk of low } \\
\text { birth weight; OR }=0.56 \text { ( } 95 \% \text { CI: } \\
0.35,0.88) \text { for highest versus lowest } \\
\text { seafood intake. }\end{array}$ \\
\hline $\begin{array}{l}\text { Vejrup et } \\
\text { al., } 2013 \\
(18)\end{array}$ & $\begin{array}{l}62,941 \text { women } \\
\text { with singleton, } \\
\text { term deliveries }\end{array}$ & $\begin{array}{l}\text { Mercury exposure } \\
\text { calculated from FFQ } \\
\text { data and a database of } \\
\text { mercury content in } \\
\text { Norwegian food }\end{array}$ & $\begin{array}{l}\text { Calculated mercury } \\
(\mathrm{Hg}) \text { intake in } \mu \mathrm{g} / \mathrm{kg} \\
\text { bw/week and divided } \\
\text { into quartiles }\end{array}$ & $\begin{array}{l}\text { Infant birth weight and } \\
\text { SGA (defined as below } \\
\text { the } 10^{\text {th }} \text { percentile } \\
\text { population growth curve) }\end{array}$ & $\begin{array}{l}\text { Newborns of mothers in the highest } \\
\text { quintile compared with the lowest } \\
\text { quintile of } \mathrm{Hg} \text { exposure had lower } \\
\text { birth weight }(-34 \mathrm{~g}) \text { and increased } \\
\text { risk of SGA, adjusted OR }=1.19 \\
(95 \% \mathrm{CI}: 1.08,1.30) \text {. }\end{array}$ \\
\hline $\begin{array}{l}\text { Duarte- } \\
\text { Salles et al., } \\
2013 \text { (19) }\end{array}$ & $\begin{array}{l}50,651 \text { women } \\
\text { with singleton } \\
\text { deliveries }\end{array}$ & $\begin{array}{l}\text { Acrylamide exposure } \\
\text { calculated from FFQ } \\
\text { data and a database of } \\
\text { acrylamide content in } \\
\text { food analysed in } \\
\text { Norway }\end{array}$ & $\begin{array}{l}\text { Acrylamide intake in } \\
\mathrm{ng} / \mathrm{kcal} / \text { day and mo- } \\
\text { delled as a continuous } \\
\text { variable and after } \\
\text { ranking into quartiles }\end{array}$ & $\begin{array}{l}\text { Infant birth weight and } \\
\text { SGA (defined as below } \\
\text { the } 10^{\text {th }} \text { percentile } \\
\text { population growth curve) }\end{array}$ & $\begin{array}{l}\text { Acrylamide intake during pregnancy } \\
\text { was associated with lower birth } \\
\text { weight and increased risk of SGA, } \\
\text { highest vs lowest quartile: birth } \\
\text { weight: }-26 \mathrm{~g}(95 \% \mathrm{CI}:-36,-15) \text {, } \\
\text { SGA: OR }=1.11 \text { ( } 95 \% \mathrm{CI}: 1.02 \text {, } \\
\text { 1.21). In smokers the association } \\
\text { was even stronger. }\end{array}$ \\
\hline $\begin{array}{l}\text { Duarte- } \\
\text { Salles et al., } \\
2013(20)\end{array}$ & $\begin{array}{l}50,651 \text { women } \\
\text { with singleton } \\
\text { deliveries }\end{array}$ & $\begin{array}{l}\text { Benzo(a)pyrene }[\mathrm{B}(\mathrm{a}) \mathrm{P}] \\
\text { exposure calculated } \\
\text { from FFQ data and a } \\
\text { database of previously } \\
\text { published B(a)P content } \\
\text { in food }\end{array}$ & $\begin{array}{l}\mathrm{B}(\mathrm{a}) \mathrm{P} \text { intake in } \\
\mathrm{ng} / \mathrm{kcal} / \mathrm{d} \text { and modelled } \\
\text { continuously (per 1-SD) } \\
\text { and in tertiles }\end{array}$ & $\begin{array}{l}\text { Infant birth weight and } \\
\text { length }\end{array}$ & $\begin{array}{l}\mathrm{B}(\mathrm{a}) \mathrm{P} \text { intake during pregnancy was } \\
\text { associated with lower birth weight } \\
\text { and length; highest vs lowest tertile } \\
-20.5 \mathrm{~g}(95 \% \mathrm{CI}:-31.1,-10.0) \text { and - } \\
0.09 \mathrm{~cm}(95 \% \mathrm{CI}:-0.15,-0.04) \text {, } \\
\text { respectively. Birth weight in women } \\
\text { in the highest vs lowest tertile of } \\
\mathrm{B}(\mathrm{a}) \mathrm{P} \text { intake were }-44.4 \mathrm{~g}(-76.5,- \\
12.3) \text { in the group with low vs }-17.6 \\
\mathrm{~g}(-29.0,-6.1) \text { in the group of high } \\
\text { vitamin } \mathrm{C} \text { intake }(<\text { or }>85 \mathrm{mg} / \mathrm{d}) \text {. }\end{array}$ \\
\hline $\begin{array}{l}\text { Papado- } \\
\text { poulou et } \\
\text { al., } 2013 \\
(21)\end{array}$ & $\begin{array}{l}50,651 \text { women } \\
\text { with singleton } \\
\text { deliveries }\end{array}$ & $\begin{array}{l}\text { Dioxins and polychlori- } \\
\text { nated biphenyls (PCB) } \\
\text { exposure calculated } \\
\text { from FFQ data and a } \\
\text { database of dioxin and } \\
\text { PCB content in } \\
\text { Norwegian food }\end{array}$ & $\begin{array}{l}\text { Calculated dioxin and } \\
\mathrm{PCB} \text { intakes in } \mathrm{pg} / \mathrm{kg} \\
\text { bw/day and divided into } \\
\text { quartiles }\end{array}$ & $\begin{array}{l}\text { Infant birth weight, } \\
\text { length, and head } \\
\text { circumference and SGA } \\
\text { (defined as below the } 10^{\text {th }} \\
\text { percentile population } \\
\text { growth curve) }\end{array}$ & $\begin{array}{l}\text { Newborns of mothers in the upper } \\
\text { intake quartile of exposure had } \\
\text { lower birth weight }(-62 \mathrm{~g}) \text {, length } \\
(-0.26 \mathrm{~cm}) \text { and head circumference } \\
(-0.10 \mathrm{~cm}) \text { than those of mothers in } \\
\text { the lowest intake quartile. No } \\
\text { association for SGA. }\end{array}$ \\
\hline $\begin{array}{l}\text { Hillesund } \\
\text { et al., } 2014 \\
(22)\end{array}$ & $\begin{array}{l}66,597 \text { mothers } \\
\text { with singleton } \\
\text { deliveries }\end{array}$ & $\begin{array}{l}\text { A New Nordic Diet } \\
\text { (NND) score con- } \\
\text { structed to reflect and } \\
\text { quantify consumption } \\
\text { of healthy and environ- } \\
\text { mentally friendly food } \\
\text { items }\end{array}$ & $\begin{array}{l}\text { NND score ranging } \\
\text { from } 0-10 \text { points was } \\
\text { divided into low ( } 0-3 \\
\text { points), medium ( } 4-5 \\
\text { points) and high } \\
\text { adherence ( } 6-10 \text { points) }\end{array}$ & $\begin{array}{l}\text { Infant birth weight and } \\
\text { gender-specific SGA, } \\
\text { AGA and LGA corre- } \\
\text { sponding to the } 10^{\text {th }} \text { and } \\
90^{\text {th }} \text { birth weight percen- } \\
\text { tiles measured in term } \\
\text { newborns to nulliparous } \\
\text { mothers in MoBa }\end{array}$ & $\begin{array}{l}\text { High as compared with low NND } \\
\text { adherence was associated with } \\
\text { lower risk of SGA }(\mathrm{OR}=0.92,95 \% \\
\text { CI: } 0.86,0.99) \text { and higher risk of } \\
\text { LGA }(\mathrm{OR}=1.07,95 \% \mathrm{CI}: 1.00 \text {, } \\
1.15) \text {. }\end{array}$ \\
\hline
\end{tabular}


Summary Table 2. Studies investigating maternal dietary quality in relation to gestational weight gain (GWG) and post-partum weight retention (PPWR) in the Norwegian Mother and Child Cohort Study.

\begin{tabular}{|c|c|c|c|c|c|}
\hline Reference & $\begin{array}{l}\text { No. of } \\
\text { participants }\end{array}$ & Dietary exposure & Exposure variables & Studied health outcome & Results \\
\hline $\begin{array}{l}\text { Hillesund } \\
\text { et al., } 2014 \\
\text { (22) }\end{array}$ & $\begin{array}{l}66,597 \text { mothers } \\
\text { with singleton } \\
\text { deliveries }\end{array}$ & $\begin{array}{l}\text { A New Nordic Diet } \\
\text { (NND) score con- } \\
\text { structed to reflect and } \\
\text { quantify consumption } \\
\text { of healthy and } \\
\text { environmentally } \\
\text { friendly food items }\end{array}$ & $\begin{array}{l}\text { NND score (range } 0- \\
10) \text { was divided into } \\
\text { low ( } 0-3 \text { points), } \\
\text { medium ( } 4-5 \text { points) } \\
\text { and high adherence } \\
\text { (6-10 points) }\end{array}$ & $\begin{array}{l}\text { Excessive gestational } \\
\text { weight gain (GWG) } \\
\text { according to the Institute } \\
\text { of Medicine (IOM) } 2009 \\
\text { criteria }\end{array}$ & $\begin{array}{l}\text { High as compared with } \\
\text { low NND adherence was } \\
\text { associated with lower risk } \\
\text { of excessive GWG in } \\
\text { normal weight women } \\
(\mathrm{OR}=0.93,95 \% \text { CI: } 0.87 \text {, } \\
0.99)\end{array}$ \\
\hline \multirow[t]{2}{*}{$\begin{array}{l}\text { Von } \\
\text { Ruesten et } \\
\text { al., } 2014 \\
(23)\end{array}$} & \multirow[t]{2}{*}{$\begin{array}{l}47,011 \text { mothers } \\
\text { with singleton } \\
\text { deliveries }\end{array}$} & \multirow{2}{*}{$\begin{array}{l}\text { Two healthy eating } \\
\text { (HEI) scores } \\
\text { measured compliance } \\
\text { with either the } \\
\text { Norwegian Food- } \\
\text { based Dietary } \\
\text { Guidelines (HEI- } \\
\text { NFG) or the nutrient- } \\
\text { based Nordic } \\
\text { Nutrition } \\
\text { Recommendations } \\
\text { (HEI-NNR). }\end{array}$} & \multirow[t]{2}{*}{$\begin{array}{l}\text { HEI-NFG score } \\
\text { (range } 0-70 \text { points) } \\
\text { and HEI-NNR score } \\
\text { (range } 0-50 \text { points) }\end{array}$} & $\begin{array}{l}\text { i) GWG as a continuous } \\
\text { variable and excessive } \\
\text { GWG (dichotomous } \\
\text { variable) derived from } \\
\text { pre-pregnant BMI and } \\
\text { IOM criteria for } \\
\text { adequate or excessive } \\
\text { weight gain }\end{array}$ & $\begin{array}{l}\text { i) HEI-NFG score } \\
\text { associated with lower } \\
\text { GWG and HEI-NNR } \\
\text { score associated with } \\
\text { higher GWG (both, as } \\
\text { continuous variable and as } \\
\text { excessive GWG) }\end{array}$ \\
\hline & & & & $\begin{array}{l}\text { ii) Post-partum weight } \\
\text { retention (PPWR) as a } \\
\text { continuous variable and } \\
\text { excessive PPWR } \\
\text { (dichotomous variable) } \\
\text { defined as } \geq 5 \% \text { weight } \\
\text { increase }\end{array}$ & $\begin{array}{l}\text { of substantial PPWR. For } 1 \\
\text { SD-increment: OR=0.96 } \\
\text { (95\% CI: } 0.94,0.99) \text { for the } \\
\text { HEI-NFG and OR=0.98 } \\
\text { (95\% CI: } 0.95,1.00) \text { for the } \\
\text { HEI-NNR score }\end{array}$ \\
\hline
\end{tabular}

NND: New Nordic Diet, HEI: Healthy Eating Index, NFG: Norwegian Food based dietary Guidelines,

NNR: Nordic Nutrition Recommendations, GWG: Gestational Weight Gain, PPWR: post-partum weight retention

dietary dioxins and PCB intake and the risk of delivering a SGA baby (21).

In a study comprising $66,597 \mathrm{MoBa}$ participants, a diet score was developed for assessing adherence to a healthy and regionally-based diet (New Nordic Diet, NND) (22). The NND score was constructed to reflect frequency of main meals, consumption of Nordic fruits, root vegetables, cabbages and potatoes, consumption of whole grains, food from the wilderness including game, fish, seafood and native berries, consumption of unsweetened milk relative to juice and consumption of water relative to sweetened beverages. The score was computed by adding ten dichotomized subscales and yielded a scoring range from 0 to 10 . The score was further divided into low (0-3 points), medium (4-5 points) and high adherence (6-10 points). High compared to low NND adherence was associated with lower risk of SGA $(\mathrm{OR}=0.92,95 \% \mathrm{CI}: 0.86,0.99)$ and higher risk of LGA (OR=1.07, 95\% CI: 1.00, 1.15).

\section{Maternal diet, weight gain during pregnancy and postpartum weight retention}

Excessive gestational weight gain (GWG) has been found to be related both with a higher risk of childhood overweight (55) and with increased weight retention of the mother in the postpartum period (5658). Two studies in MoBa examined maternal diet in relation to weight gain during pregnancy and/or postpartum weight retention (Summary Table 2).

Adherence to the NND score, described above, was also studied in relation to gestational weight gain. In the study with 66,597 participants, high versus low NND scores were associated with lower risk of excessive gestational weight gain in women with a prepregnant body mass index lower than $25 \mathrm{~kg} / \mathrm{m}^{2}$ (22). Excessive weight gain was defined according to the Institute of Medicine (IOM) criteria for BMI-specific recommended weight-gain, released in 2009.

In another study, two healthy eating indexes (HEI) were developed and examined in relation to gestational weight gain and post-partum weight retention (23). The two HEI scores measured compliance with either the Norwegian Food-based Dietary Guidelines (HEINFG) or the nutrient-based Nordic Nutrition Recommendations (HEI-NNR). Higher adherence to the HEINFG score was associated with lower gestational weight gain, while the HEI-NNR score was associated with higher gestational weight gain. Furthermore, the HEI-NFG was associated with lower postpartum weight retention six months after delivery, while no statistically relevant association was found for the HEI-NNR. However, when that outcome was modelled as excessive postpartum weight retention $(\geq 5 \%$ increase relative to pre-pregnant weight), both indices were associated with lower risk of substantial weight retention six months after delivery. The OR per 1 SDincrement was 0.96 (95\% CI: 0.94, 0.99) for the HEINFG score and 0.98 (95\% CI: $0.95,1.00)$ for the HEINNR score. Thus, adherence to food-based dietary guidelines as measured by the HEI-NFG appear to have a stronger impact on prevention of adverse maternal weight development compared to the nutrient-based recommendations, as indicated by the HEI-NNR (23). 


\section{Maternal diet and preeclampsia}

Preeclampsia is a condition characterized by pregnancy induced hypertension which may involve dysfunction of many organ systems including reduced perfusion of the placenta, and endothelial dysfunction. The diagnostic criteria for preeclampsia in Norway are blood pressure $\geq 140 \mathrm{~mm} \mathrm{Hg}$ systolic or $90 \mathrm{~mm} \mathrm{Hg}$ diastolic after 20 weeks' gestation combined with proteinuria greater than +1 dipstick on at least 2 occasions. Preeclampsia is one of the major causes of maternal and foetal morbidity and mortality $(59,60)$. The aetiology is largely unknown. Several studies have indicated associations between maternal diet and the risk of developing preeclampsia and four studies have investigated maternal diet and preeclampsia in $\mathrm{MoBa}$ (Summary Table 3).

A study in 23,423 nulliparous women investigated overall dietary quality and the risk of developing preeclampsia. Four distinct dietary patterns were identified using principal component analysis (24). The principal components (denoting dietary patterns) reflect overall dietary behaviour and take into account the correlation between all consumed food items. The overall prevalence of preeclampsia was $5.4 \%$. A pattern characterized by vegetables, plant food and vegetable oils (denoted the 'Vegetable' pattern) was associated with reduced risk of preeclampsia (OR for high versus low adherence defined by tertiles of pattern scores: 0.72 (95\% CI: $0.62,0.85)$. A pattern characterized by processed meat products, salty snacks and sweet drinks (denoted the 'Processed' pattern) was associated with an increased risk $(\mathrm{OR}=1.21,95 \% \mathrm{CI}: 1.03,1.42)$. The results suggested that increasing the intake of vegetables, fruits, whole grains and vegetable oils and reducing the intake of processed meats and sweet beverages may be beneficial (24).

The associations between intakes of vitamin D and marine long-chain n-3 fatty acids in relation to preeclampsia were investigated in the same population as the above study (25). Vitamin D and marine fatty acids are largely contributed by the same foods and dietary supplements, particularly cod liver oil and fish oil supplements, which were the supplements reported most frequently in pregnancy (12). The results showed a protective effect of vitamin $\mathrm{D}$ on risk of developing preeclampsia, consistent with previous reports $(61,62)$. The risk of developing preeclampsia was lower in women with a total vitamin D intake of 15-20 $\mu \mathrm{g} /$ day in comparison to those with an intake less than 5 $\mu \mathrm{g} /$ day, with $\mathrm{OR}=0.76$ ( $95 \%$ CI: $0.60,0.95)$. Considering the intake of vitamin D from supplements only, there was a $27 \%$ risk reduction $(\mathrm{OR}=0.73,0.58,0.92)$ for women getting $10-15 \mu \mathrm{g} /$ day of supplementary vitamin D as compared with no vitamin D from supplements. No associations with preeclampsia were found for intake of vitamin D from food only, or for intake of marine long-chain fatty acids from food or supplements (25).

Probiotics, defined as live microorganisms that, when administered in adequate amounts, confer a health benefit on the host, have been suggested to modify placental trophoblast inflammation, systemic inflammation, and blood pressure, all potentially interesting aspects of preeclampsia (63-65). Based on the hypothesis that probiotic lactobacilli might reduce inflammation, the association between maternal intake of probiotic milk products and preeclampsia was examined in 33,399 nulliparous women (26). The prevalence of preeclampsia was $5.3 \%$. During the time of dietary assessment very few products enriched with probiotic lactobacilli were available in Norway. These products were mainly two types of milk and one type of yoghurt, and the FFQ had separate questions to capture the consumption of these items. The probiotic milk products contained either all or the two first of the following strains: Lactobacillus acidophilus LA-5, Bifidobacterium lactis $\mathrm{Bb} 12$, Lactobacillus rhamnosus GG. The results showed that women who reported an intake of probiotic milk products had lower risk of preeclampsia than those who reported no intake. With probiotic food intakes divided into categories representing none, monthly, weekly, or daily intake, lower risk for preeclampsia was observed for daily probiotic intake (OR $=0.80,95 \%$ CI: 0.66, 0.96). Lower risks for severe preeclampsia were observed for weekly $(\mathrm{OR}=$ $0.75,95 \%$ CI: $0.57,0.98)$ as well as daily intakes (OR $=0.61,95 \%$ CI: $0.43,0.89$ ).

Preeclampsia risk was also examined with regard to intake of food items with high content of either added or natural sugars (27). High sugar content was defined as $10 \mathrm{~g}$ of sugar or more per $100 \mathrm{~g}$ of food. High intakes of sugar-sweetened carbonated and/or noncarbonated beverages were significantly associated with an increased risk of preeclampsia, with OR for the combined beverages 1.27 (95\% CIs: $1.05,1.54)$ for high intake ( $\geq 125 \mathrm{ml} /$ day) compared to no intake. Contrary to this, the intake of foods with a high content of natural sugars, such as fresh and dried fruits, was associated with a decreased risk of preeclampsia, suggesting that foods with a high content of added sugar and foods with naturally occurring sugars are differently associated with preeclampsia.

\section{Maternal diet and preterm delivery}

Preterm delivery, defined as spontaneous or medically induced delivery before gestational week 37 , is the major cause of perinatal mortality and morbidity and is an important risk factor of long-term physical and mental disabilities (66-70). The aetiology of spontaneous preterm delivery is poorly understood but, as for other pregnancy outcomes, studies have indicated associations between maternal diet and the risk of preterm delivery. Five studies have investigated maternal diet and preterm delivery and/or spontaneous preterm delivery in MoBa (Summary Table 4).

A Mediterranean-type diet has been shown to reduce the incidence of preterm delivery (71). The association between adherence to a Mediterranean-type diet (MD) 
Summary Table 3. Studies investigating maternal dietary factors and preeclampsia in the Norwegian Mother and Child Cohort Study.

\begin{tabular}{|c|c|c|c|}
\hline Reference & $\begin{array}{l}\text { No. of } \\
\text { participants }\end{array}$ & Dietary exposure & Exposure variables \\
\hline $\begin{array}{l}\text { Brantsæter } \\
\text { et al., } 2009 \\
(24)\end{array}$ & $\begin{array}{l}23,423 \\
\text { nulliparous } \\
\text { women }\end{array}$ & $\begin{array}{l}\text { Dietary patterns were } \\
\text { identified from } 58 \\
\text { non-overlapping agg- } \\
\text { regated food groups } \\
\text { using principal } \\
\text { component analysis }\end{array}$ & $\begin{array}{l}\text { Four dietary patterns } \\
\text { were identified and } \\
\text { denoted: 'Vegetable', } \\
\text { 'Processed', 'Potato } \\
\text { and fish' and 'Cakes } \\
\text { and sweets'. Pattern } \\
\text { scores were divided } \\
\text { into tertiles }\end{array}$ \\
\hline
\end{tabular}

$\begin{array}{lll}\text { Haugen et } & 23,423 & \text { Vitamin D calculated } \\ \text { al., 2009 } & \text { nulliparous } & \text { from food and dietary } \\ (25) & \text { women } & \text { supplements }\end{array}$

$\begin{array}{ll}33,399 & \text { Milk products } \\ \text { nulliparous } & \text { containing probiotic } \\ \text { women } & \text { lactobacilli }\end{array}$

Borgen et al., 2012 (27)

\begin{tabular}{|c|c|c|}
\hline $\begin{array}{l}32,933 \\
\text { nulliparous } \\
\text { women } \\
\text { without } \\
\text { diabetes }\end{array}$ & $\begin{array}{l}\text { Maternal intake of } \\
\text { added sugar and } \\
\text { food/drink items with } \\
\text { high content of added } \\
\text { or natural sugar }(\sim 10 \\
\text { g simple carbo- } \\
\text { hydrates per } 100 \mathrm{~g})\end{array}$ & $\begin{array}{l}\text { Intake variables were } \\
\text { modelled both as } \\
\text { continuous variables } \\
\text { (g/d) and as ranked } \\
\text { categories (quartiles) }\end{array}$ \\
\hline
\end{tabular}

Total intake divided into 5 categories and supplement intake divided into 6 categories

Probiotic consumption as a dichotomous variable (no/yes) and in 4 categories representing no, low (less than weekly), medium (weekly) and high (daily intake)

Studied health outcome Results

Preeclampsia $^{\S}$ as Upper vs lower third of the

registered in the Medical 'Vegetable' pattern was Birth Registry and associated with reduced risk diagnosed according to $\quad(\mathrm{OR}=0.72,95 \% \mathrm{CI}: 0.62,0.85)$, international criteria and upper vs lower third of the 'Processed' pattern was associated with increased risk $(\mathrm{OR}=1.21,95 \% \mathrm{CI}: 1.03,1.42)$ of preeclampsia.

Preeclampsia $^{\S}$ as

No association between vitamin registered in the Medical $\mathrm{D}$ from food only, but lower Birth Registry and risk for total vitamin D intake diagnosed according to of 15-20 $\mu \mathrm{g}$ /day compared with international criteria $\quad<5 \mu \mathrm{g}$ /day $(\mathrm{OR}=0.73,95 \% \mathrm{CI}$ : $0.58,0.92)$.

\section{Preeclampsia ${ }^{\S}$ as} In comparison with no intake, registered in the Medical daily intake of probiotic milk Birth Registry and products was associated with diagnosed according to lower risk of overall $(\mathrm{OR}=0.80$, international criteria. $\quad 95 \% \mathrm{CI}: 0.66,0.96)$ and severe Additional analyses of $\quad$ preeclampsia $\mathrm{OR}=0.61,95 \%$ subtypes early, late, mild CI: $0.43,0.89$ ). and severe preeclampsia Preeclampsia
registered in the Medical Birth Registry and diagnosed according to international criteria
Added sugar was not associated of sugar-sweetened (carbonated and non-carbonated drinks) was associated with increased risk, with OR for upper versus lower third 1.27 (95\% CI: $1.05,1.54)$.

\footnotetext{
${ }^{\S}$ Preeclampsia includes HELLP (hemolysis, elevated liver enzymes, low platelet count), eclampsia, early preeclampsia (diagnosed before 34 gestational weeks), mild preeclampsia and severe preeclampsia. Diagnostic criteria according guidelines issued by the Society for Gynecology: Blood pressure $>140 / 90$ after 20 wk of gestation, combined with proteinuria $>+1$ dipstick on at least 2 occasions.
}

and risk of preterm delivery was examined in $\mathrm{MoBa}$ (28). The study sample comprised 26,563 non-smoking women who had a BMI between 19 and $32 \mathrm{~kg} / \mathrm{m}^{2}$, were between 21 and 38 years old and delivered a singleton live baby. A Mediterranean diet score was constructed based on five criteria: 1) the intake of fish twice a week or more, 2) the intake of fruit and vegetables five times a day or more, 3 ) the use of olive/canola oil, 4) red meat intake less than twice a week, and 5) less than two cups of coffee a day. Only 569 (2.2\%) women met all the MD criteria. There was no association between fulfilling all the MD criteria and preterm delivery. However, when the five MD criteria were analysed separately, a lower risk of preterm delivery was found in those who fulfilled the 'intake of fish twice a week or more' criteria, with adjusted $\mathrm{OR}=0.84(95 \% \mathrm{CI}$ : $0.74,0.95)(28)$.

Myhre et al. (2010) hypothesized that intake of food with probiotics might influence and reduce the rate of spontaneous preterm delivery based on a putative direct effect of probiotics on vaginal tract infections and reduced systemic inflammation (29). The study sample comprised 18,888 healthy pregnant women in $\mathrm{MoBa}$ with spontaneous onset of delivery resulting in a live singleton baby. Of 18,888 deliveries, 950 (5.0\%) were preterm. Intake of milk products containing probiotic bacteria as described in the previously discussed outcome - preeclampsia (consumption versus nonconsumption), was associated with a reduced risk of spontaneous preterm delivery, adjusted $\mathrm{OR}=0.86(95 \%$ CI: $0.74,0.99)$. When grouped into none, low and high intake, a weak dose-response effect was indicated (29).

In the same study population as above $(18,888$ healthy pregnancies), food items assumed to contain antimicrobial compounds were also examined with regard to the outcome spontaneous preterm delivery (30). An extensive literature review identified two main food types, alliums (garlic, onions and leek) and dried fruits (raisins, apricots, prunes, figs and dates) that contain antimicrobial components with activity towards microbes previously associated to PTD. Intakes of alliums and dried fruits were associated with reduced risk of spontaneous preterm delivery (adjusted $\mathrm{OR}=0.82,95 \% \mathrm{CI}: 0.72,0.94$ for both). Allium intake was associated with reduced risk of early spontaneous (gestational weeks 28-31) preterm delivery (adjusted $\mathrm{OR}=0.39,95 \% \mathrm{CI}: 0.19,0.80)$ while dried fruits were associated with a reduced risk of preterm prelabor rup- 
Summary Table 4. Studies investigating maternal dietary factors and preterm delivery in the Norwegian Mother and Child Cohort Study.

\begin{tabular}{|c|c|c|c|c|c|}
\hline Reference & $\begin{array}{l}\text { No. of } \\
\text { participants }\end{array}$ & Dietary exposure & Exposure variables & Studied health outcome & Results \\
\hline $\begin{array}{l}\text { Haugen et } \\
\text { al., } 2008 \\
(28)\end{array}$ & $\begin{array}{l}26,563 \text { non- } \\
\text { smoking women } \\
\text { with BMI range } \\
19-32 \mathrm{~kg} / \mathrm{m}^{2}, \text { age } \\
\text { range } 21-38 \\
\text { years and who } \\
\text { delivered a } \\
\text { singleton, live }\end{array}$ & $\begin{array}{l}\text { A Mediterranean diet } \\
\text { score (MD) based on } \\
\text { five criteria: fish } \geq 2 \\
\text { times/week, fruit and } \\
\text { vegetables } \geq 5 \text { times/day, } \\
\text { use of olive/canola oil, } \\
\text { red meat } \leq 2 \text { times/week } \\
\text { and coffee } \leq 2 \text { cups/day }\end{array}$ & $\begin{array}{l}\text { Women complying with } \\
\text { all } 5 \text { criteria versus } \\
\text { those complying with } 0 \\
\text { criteria, women } \\
\text { complying with all } 5 \\
\text { versus those complying } \\
\text { with } 1-4 \text { criteria and all } \\
5 \text { criteria analyzed }\end{array}$ & $\begin{array}{l}\text { Preterm delivery }(<37 \\
\text { gestational weeks), early } \\
\text { preterm }(<35 \text { gestational } \\
\text { weeks), late preterm }(35- \\
37 \text { gestational weeks) }\end{array}$ & $\begin{array}{l}\text { No associations between } 5 \text { vs } 0 \text { or } 5 \\
\text { vs } 1-4 \text { MD criteria. When the } 5 \text { MD } \\
\text { criteria were analyzed separately, } \\
\text { only fish } \geq 2 \text { times/week was } \\
\text { associated with reduced risk of } \\
\text { preterm delivery, adjusted OR }=0.84 \\
(95 \% \text { CI: } 0.74,0.95) \text {. }\end{array}$ \\
\hline
\end{tabular}

Sengpiel et 49,102 women al., $2013 \quad$ with singleton,

\section{Total caffeine and Caffeine, total and from} caffeine from individual different sources as items: i) Allium and artificially (16) uncomplicated spontaneous deliveries sources based on the FFQ, and caffeine intake prior to pregnancy, in $1^{\text {st }}$ and $3^{\text {rd }}$ trimester
Myhre et
al., 2010 (1)

Myhre et al., 2013 (30)
18,888 healthy women aged 20 to 35 years with spontaneous delivery of a live, singleton 18,888 healthy women aged 20 to 35 years with spontaneous delivery of a live, singleton

Englund60,761 pregnant non-diabetic women with live singleton deliveries

Milk products
Ögge et al.,
Antimicrobial food vegetables (onion, leek, garlic) and ii) Dried fruits (raisins, apricots, prunes) containing probiotic lactobacilli

Sugar-sweetened (SS) sweetened (AS) drinks, carbonated and noncarbonated combined for each type continuous variables and total caffeine ranked into sixtiles, and divided into categories representing 0-50, 51$200,201-300$ and $>300$ $\mathrm{mg} /$ day

Probiotic consumption as a dichotomous variable (no/yes) and grouped into categories representing no, low and high intake

Food intakes of interest as dichotomous variables (consumers vs non-consumers) and grouped into categories representing no, low/medium and high intake

\section{SS and AS drinks} grouped into i) 6 categories ranging from no intake to 4 or more servings per day, and ii) same as above but with the three highest categories combined into 1 or more serving per day singleton deliveries
Englund66,000 pregnant non-diabetic women with live

Dietary patterns were identified from 58 non2014 (32) overlapping aggregated food groups using principal component analysis.

$\begin{array}{ll}\text { Sengpiel et } & 66,014 \text { women } \\ \text { al., 2014 } & \text { with live, } \\ \text { (33) } & \text { singleton } \\ & \text { deliveries }\end{array}$

Folate contributed by food and from dietary supplements. Median intake of food folate and supplemental folic acid was 157 and 143 $\mu \mathrm{g} /$ day, respectively
Three dietary patterns were identified ('Prudent', 'Western' and 'Traditional') and scores on all patterns were modelled i) as continuous variables and ii) ranked into tertiles

Total amount of folate intake from the diet or supplements as continuous variables, total folate ranked into deciles, and total folate divided into four categories
Preterm delivery $(<37$ gestational weeks), early preterm (22-33 gestational weeks), late preterm (34-36 gestational weeks)

Spontaneous preterm delivery (delivery before 37 gestational weeks)

Spontaneous preterm delivery (sPTD) (delivery before 37 gestational weeks) and preterm prelabor rupture of membranes (PPROM)

Preterm delivery $(<37$ weeks) as well as early (22-31 weeks), moderate $(32-33 \mathrm{w})$ and late (34-36 weeks), as well as spontaneous and iatrogenic
Neither total nor coffee caffeine was associated with spontaneous PTD risk. (medically induced PTD)

Intake of probiotic milk products preeclampsia, high vs no intake adjusted $\mathrm{OR}=0.82$ (95\% CI: 0.68 , 0.99).

Intakes of alliums and dried fruit were associated with reduced risk of sPTD (OR=0.82, 95\% CI: 0.72, 0.94 for both). Allium intake was particularly related to early sPTD (adjusted OR $=0.39,95 \%$ CI: 0.19 , 0.80 ) and dried fruits intake particularly related to PPROM $(\mathrm{OR}=0.74,95 \%$ CI: 0.65, 0.95).

Compared with no intake, daily intakes of both AS and SS drinks were associated with increased risk of overall PTD. Intake $\geq 1$ serving/day: adjusted $\mathrm{OR}=1.11$ $(95 \%$ CI: $1.00,1.24)$ for AS drinks and $\mathrm{OR}=1.25$ (95\% CI: $1.08,1.45)$ for SS drinks. AS beverages was also associated with spontaneous PTD: adjusted OR=1.15 (95\% CI: 1.01, 1.32).

Preterm delivery (PTD) defined as delivery $<37$ gestational weeks, subcategories spontaneous (sPTD) and iatrogenic (medically induced), and subcategories early (22-31 weeks), moderate (32-33 weeks) and late (34-36 weeks) PTD

Spontaneous preterm delivery (sPTD) (delivery before 37 gestational weeks)

Upper vs lower third of the 'Prudent' and 'Traditional' pattern was associated with lower risk of PTD [adjusted HR=0.88 (CI: 0.80, $0.97)$ and $\mathrm{HR}=0.91(0.83,0.99)$ respectively].The 'Prudent' pattern was particularly associated with late PTD (HR $=0.86,95 \%$ CI: 0.78, 0.96) and with $\mathrm{SPTD}(\mathrm{HR}=0.85,95 \% \mathrm{CI}$ : $0.75,0.96$ ).

The amount of folate intake from foods and from the folic acid supplements was not associated with the risk of $\mathrm{sPTD}(\mathrm{HR}=1.00,95 \% \mathrm{CI}$ : was associated with reduced risk of $1.00,1.00)$. Initiation of folic acid supplementation more than 8 weeks before conception was associated with increased risk for sPTD $(\mathrm{HR}=1.18,95 \%$ CI: $1.05,1.32)$ compared to no folic acid supplementation preconception. There was no significant association with sPTD when supplementation was initiated within 8 weeks preconception (HR=0.99, CI: 0.87, 1.13). 
ture of membranes (OR=0.74, 95\% CI: $0.65,0.95)$.

Artificially sweetened (AS) and sugar-sweetened (SS) beverages are commonly consumed during pregnancy. A study comprising 60,761 women in MoBa examined whether the intake of AS and SS beverages was associated with preterm delivery. Beverage consumption was reported in all three self-administered questionnaires answered during pregnancy and covered intakes prior to pregnancy, and in early, mid and late pregnancy (31). Intakes of AS and SS beverages were mutually adjusted. The results showed that women with daily intakes of either AS and/or SS drinks had higher risk of preterm delivery. For intake of at least one serving daily compared with no intake, the OR was $1.11(95 \%$ CI: $1.00,1.24)$ for AS drinks, and 1.25 ( $95 \%$ CI: $1.08,1.45)$ for SS drinks. AS beverages was also associated with spontaneous preterm delivery $(\mathrm{OR}=1.15,95 \%$ CI: 1.01, 1.32). Reanalysis of the data with AS and SS beverage intakes before pregnancy did not change the results. The data did not indicate a shift from SS drinks to AS drinks with progression of pregnancy.

Maternal caffeine intake and caffeine from different sources was studied not only in relation to fetal growth (summarized above), but also in relation to preterm delivery (16). The study population comprised 59,123 healthy mothers, of whom 49,102 delivered spontaneously and $1,451(3.0 \%)$ were preterm. There was no significant association between total or coffee caffeine intake and the odds for overall, early $(<34$ gestational weeks) or late (34-36 gestational weeks) spontaneous preterm delivery.

To study maternal diet in a broader view, associations between dietary patterns and preterm delivery were examined in a sample of 66,000 women. Three distinct dietary patterns were identified, denoted "prudent" (for example, vegetables, fruits, oils, water as beverage, whole grain cereals, fiber rich bread), "Western" (salty and sweet snacks, white bread, desserts, processed meat products), and "traditional" (potatoes, fish, boiled vegetables). Lower risk of preterm delivery was found for increasing scores both for the "prudent" and the "traditional" patterns, with HR for the highest versus the lowest third being 0.88 (95\% CI: 0.80 to 0.97$)$ and $0.89(95 \%$ CI: $0.78,0.99)$ respectively. The prudent pattern was also associated with lower risk of late (34-36 weeks) and spontaneous preterm delivery (32).

The detailed assessment of dietary supplement use in MoBa covers the period prior to pregnancy as well as during pregnancy. The association between maternal folate intake from food and supplements and the risk of spontaneous preterm delivery was examined in 66,014 women with singleton pregnancies resulting in live births in years 2002 to 2009 . The association of folic acid supplementation with preterm delivery was also studied with total folate intake grouped into four categories $(<170 \mu \mathrm{g} / \mathrm{d}, 170-500 \mu \mathrm{g} / \mathrm{d} 500-1000 \mu \mathrm{g} / \mathrm{d}$ and $>1000 \mu \mathrm{g} / \mathrm{d}$ ). The total amount of folate from food and from folic acid supplements was not significantly associated with the risk of preterm delivery. Initiation of folic acid supplementation more than 8 weeks before conception was associated with an increased risk of spontaneous preterm delivery compared to no folic acid supplementation preconception $(\mathrm{HR}=1.18$; $95 \%$ CI $1.05,1.32$ ), but no significant association with preterm delivery was found when supplementation was initiated within 8 weeks prior to conception ( $\mathrm{HR}=0.99$; $95 \%$ CI $0.87,1.13)(33)$.

\section{DiscuSSION}

\section{Main findings}

The overall results from MoBa studies of maternal diet and pregnancy outcomes show that healthy eating, as defined in official recommendations to the public, is associated with lower risks of adverse clinical pregnancy outcomes and complications. Healthy eating in these studies was characterised by regular intake of vegetables, fruit, whole grain, fish, probiotic milk products, water for drinking and lower intake of sugar sweetened beverages, processed meat products and salty snacks. These are typical features of a diet recommended to the general public as a way to reduce the risk of chronic diseases $(72,73)$.

In Norway, the dietary advice to the general healthy population (including pregnant women) from national health authorities incorporates quantitative recommendations on the following dietary components: fresh fruit (minimum $300 \mathrm{~g} /$ day), vegetables (300-450 $\mathrm{g}$ /day), whole-grain (75 g/10 MJ corresponding to 70 $\mathrm{g}$ /day for women), fish (300-450 g/week of which fatty fish minimum 200 to maximum $450 \mathrm{~g} /$ week), red meat (maximum $500 \mathrm{~g} / \mathrm{week}$ ), limited consumption of processed meat, salt (maximum $6 \mathrm{~g}$ salt/day $\approx 2.4 \mathrm{~g}$ sodium) and added sugar (maximum $10 \%$ of total energy intake) (74). Furthermore, special advice is given to pregnant women to abstain from intake of alcohol, to limit the intake of caffeine containing beverages, to reduce the intake of food items known to contain environmental contaminants, e.g. seagull-eggs and fish liver. Folic acid supplementation is recommended to all women who plan to become pregnant and for the first three months of pregnancy. Pregnant women are also recommended to use a vitamin D supplement daily (75). Routine iron supplementation during pregnancy is not recommended in Norway due to the risk of adverse effects (76).

Adherence to the food based dietary guidelines mentioned above was evaluated in the study by von Ruesten et al. (23). In MoBa participants, the recommended intakes were reached by $33 \%$ for fruit, $7 \%$ for vegetables, $61 \%$ for whole grains, $23 \%$ for fish, $45 \%$ for red meat, and $51 \%$ for added sugar. Although pregnant women in general are motivated to choose a healthy diet, the results show that there is a large po- 
tential for improvement. When intakes, e.g. of allium vegetables or fish, were associated with reduced risk of an adverse pregnancy outcome, the results suggested that even small changes may be of clinical importance. In studies using the data-driven dietary patterns as the exposure, pattern scores cannot be interpreted in terms of food amounts, but the patterns identify food groups of particular importance, e.g. vegetables and plant foods as cornerstones of a healthy diet. As a whole, the $\mathrm{MoBa}$ diet studies contribute supporting evidence for the current dietary guidelines.

A consistent dose-response association was found for caffeine intake, lower birth weight and increased risk of SGA (16). The estimated effects were very similar to what was also found in a study with 2,635 low risk pregnant women in the UK (77). These two studies together provide strong evidence of a link between caffeine intake and growth restriction as they, contrary to most previous studies (78), were able to take into account caffeine intake from different sources as well as a number of potential confounding factors including pregnancy symptoms and smoking. The results did not indicate any threshold for an effect of caffeine on birth weight or SGA and suggest that, for this pregnancy outcome, the current limits for acceptable caffeine intake (200-300 mg/day) may be too high and need to be re-evaluated. However, no association between caffeine intake and preterm delivery was observed, which is in line with a metaanalysis of 15 cohort and 7 case control studies which concluded that there is no evidence of a link between caffeine intake and preterm delivery (79).

\section{Possible explanations for findings and comparison with other studies}

There are several potential biological mechanisms that could explain the associations between maternal diet and risk of adverse pregnancy outcomes observed in these MoBa studies. Vegetables, fruits and whole grains are sources of dietary fibre, vitamins, minerals and a wide range of bioactive compounds, including phytochemicals, antioxidants and secondary plant metabolites (80). It has been indicated that these substances directly, or indirectly, through prompting a favourable gut microbiota, can have an impact on inflammation, blood pressure and blood lipids (81-83). Sugar, fat, and processed foods, on the other hand, may lead to unfavourable blood pressure, blood lipid patterns and gut microbiota $(82,84)$. It has also been indicated that maternal diet affects microbes identified at the important maternal-fetal interface of the placenta $(85,86)$. Both preeclampsia and preterm delivery are conditions characterised by disturbed inflammatory responses $(87,88)$. Hence the mechanism for the beneficial effects of certain diets on the risk of preeclampsia and preterm delivery may be through reduced inflammation due to intake of vegetables $(24,30,32)$ and probiotic food $(26,29)$. In a follow up of children of mothers who reported use of probiotic food, we also found an indication of reduced risk of allergic disease in children 3 years of age (36). These studies support the hypothesis that diet is closely linked to gut microbiota and immune responses.

The beneficial effect of fish consumption on foetal growth was confirmed in a meta-analysis of fish intake during pregnancy and foetal growth and gestational length in 19 European birth cohorts, including MoBa. The meta-analysis concluded that moderate fish intake during pregnancy is associated with lower risk of preterm delivery and a small but significant increase in birth weight (89). Of particular interest is the observation we made in MoBa that it is mainly lean fish that is associated with the beneficial effect on foetal growth (17). Although these findings cannot establish causality, they support the need for public health advice to promote varied fish consumption in pregnant women, but in accordance with country-specific restrictions regarding fish species known to have high concentrations of pollutants.

Increasing maternal $\mathrm{Hg}$ exposure was associated with lower infant birth weight in all strata of fish intake (18), but still there was a positive effect of seafood consumption, and clarification is needed to identify at what level of $\mathrm{Hg}$ exposure this risk might exceed the benefits of seafood. The same was observed for PCB and dioxins (21). Hence, these results show that seafood consumption during pregnancy should not be avoided, but continued surveillance and advice is needed in order to avoid consumption of the most contaminated species (75).

Maternal intakes of two other potentially harmful dietary components, acrylamide and $\mathrm{B}(\mathrm{a}) \mathrm{P}$, both formed during heating of food, were associated with reduced infant birth weight. Snacks, fried potatoes and crisp bread are the major sources of acrylamide in the MoBa cohort (19), while the foods which most strongly predicted high intakes of $\mathrm{B}(\mathrm{a}) \mathrm{P}$ were shellfish and processed/cure meat (20). The most interesting finding in the B(a)P study was the modifying effect of vitamin C. Consumption of fresh fruit and vegetables has been shown to modify the formation of bulky DNA adducts in cord blood (90) and in adults (91). However, the understanding of underlying mechanisms to explain this effect modification is still incomplete.

There is strong evidence linking low maternal folate status to increased risk of neural tube defects in the new born babies (92). Increased intake of this Bvitamin has also been associated with reduced risk of other congenital malformations and adverse pregnancy outcomes (93). However, no association of plasma folate, folate from food or folic acid from supplements was found with birth size (15). This result differed from the result of a systematic review and meta-analysis including eight randomized controlled studies, which indicated a $2 \%$ increase in infant birth weight for every two-fold increase in folate intake (94). No association between intake of total folate and preterm delivery was found in MoBa (33), which is in line with the mentioned systematic review and meta-analysis (94). 


\section{Strengths and limitations}

There are both strengths and limitations in our studies. The major strengths are the prospective design of $\mathrm{MoBa}$, the large sample size and the extensive information about relevant confounding factors. Most important, maternal diet was assessed prior to delivery and women were not aware of the outcome of their pregnancy, so outcome could not affect the reporting. Pregnant women were recruited from all parts of Norway and the large study sample includes women with a wide range of age, background, socio-economic level and lifestyle. Through linkage to the medical birth registry it is possible not only to obtain validated pregnancy outcomes, but also to include information about previous pregnancy outcomes, e.g. previous preterm delivery, which is the strongest risk factor for preterm delivery in subsequent pregnancies. In the FFQ, which was answered in gestational week 17-22, women were asked to report average intake since the beginning of pregnancy. Hence, the FFQ covered the embryogenesis period that is important through epigenetic mechanisms.

These studies in MoBa also have limitations. Firstly, all dietary assessments are susceptible to measurement error, and misreporting cannot be ruled out. Furthermore, it has been shown that foods perceived as unhealthy, such as fats, sweets, desserts and snacks, tend to be underreported to a larger degree than foods perceived as healthy, and this phenomenon has been reported also in pregnant populations $(47,95)$. Dietary intake is notoriously difficult to measure because of recall errors, potential misreporting, and the difficulty of assessing portion sizes. The FFQ method has been criticized for being a crude and imprecise instrument (96). It challenges respondents with complex cognitive tasks by asking about their average over a given time period, and is particularly difficult to answer during the first part of pregnancy when many women experience nausea/vomiting and changes in appetite and eating patterns. Extensive validation comprised evaluation of major food groups (e.g. vegetables, fruit, milk/dairy, fish/seafood), nutrients (e.g. protein, fat, vitamin D, iodine) and toxicants (e.g. mercury, acrylamide), using another dietary method as well as biological markers of intake as reference methods (4649,97). The validation study demonstrated that the FFQ was able to correctly rank respondents according to high and low intakes of foods, nutrients and unwanted substances (e.g. acrylamide). However, the correlation coefficients between the test and reference methods were generally weaker than correlations found in non-pregnant populations. Low precision in the dietary assessment will attenuate potential diet (exposure)-outcome associations towards the null and imply that when significant associations are observed, the 'true association' is likely to be stronger than the observed association (98).

The participation rate in MoBa is a cause of con- cern. During the recruitment period 1999-2009 around $60 \%$ of those invited to participate did not give their consent. Consequently, there is a concern as to what extent the results of MoBa are valid for the total pregnant population. In two separate studies, Nilsen et al. examined potential self-selection bias in MoBa by comparing exposure-outcome associations from the cohort to similar associations obtained from the Medical Birth Registry of Norway $(99,100)$. Despite differences in prevalence estimates between the cohort participants and the total population of pregnant women, no statistically relative differences in association measures were found, e.g. prenatal smoking and low birth weight $(<2500 \mathrm{~g})$, maternal vitamin use and placental abruption, and parity and preeclampsia (99). It is a strength that the women who do participate remain in the study, illustrated by a response rate of more than $90 \%$ for the three extensive questionnaires answered during pregnancy.

\section{Conclusion and policy implications}

The studies of maternal diet and pregnancy outcomes summarised in this paper adds to the evidence that maternal diet may modify pregnancy outcomes, and that increasing the daily intake of healthy foods like vegetables, fruit, whole grain, fish, dairy and water for drinking is of clinical importance. New observations are the finding that particularly lean fish explained the positive association between seafood intake and foetal growth, and the indications of a protective effect of probiotic (e.g. milk products enriched with probiotic lactobacilli) and antimicrobial foods (e.g. alliums and dried fruit as examples of food items which stimulate growth of 'good' microbes in the gut) on pregnancy outcomes. This points to the importance of diet composition for a healthy gut flora and the body's immune response. However, the findings are observational, and cannot be used as evidence of causal inference, but should be used as basis for further studies exploring possible causal relationships and mechanisms, e.g. using biomaterial sampled in MoBa.

Dietary changes have low cost and low risk compared to medical interventions, and the results corroborate that current official recommendations and advice, with the exception of caffeine, are sound. The adverse association of caffeine with birth weight and SGA found in MoBa confirm previous studies, and taken together, these studies suggest that current upper limits for caffeine intake in pregnancy should be reevaluated. To our surprise we also found indications of a negative impact of some environmental and food processing contaminants even at low levels. This should reinforce further reduction of chemical pollutants, which might end up in the food chain. Furthermore, this should encourage pregnant women to eat a healthy diet and inspire medical practitioners to enhance the message that fertile women should maintain a healthy diet both before and during pregnancy. 


\section{REFERENCES}

1. Wei SQ, Fraser W, Luo ZC. Inflammatory cytokines and spontaneous preterm birth in asymptomatic women: a systematic review. Obstet Gynecol 2010;116(2 Pt 1):393-401.

2. Clerici G, Slavescu C, Fiengo S, Kanninen TT, Romanelli M, Biondi R, et al. Oxidative stress in pathological pregnancies. J Obstet Gynaecol 2012;32(2):124-7.

3. Godfrey KM, Barker DJ. Fetal programming and adult health. Public Health Nutr 2001;4(2B):611-24.

4. Moore VM, Davies MJ. Diet during pregnancy, neonatal outcomes and later health. Reprod Fertil Dev 2005; 17(3):341-8.

5. Kind KL, Moore VM, Davies MJ. Diet around conception and during pregnancy - effects on fetal and neonatal outcomes. Reprod Biomed Online 2006;12(5):532-41.

6. Blumfield ML, Hure AJ, MacDonald-Wicks LK, Smith R, Simpson SJ, Giles WB, et al. Dietary balance during pregnancy is associated with fetal adiposity and fat distribution. Am J Clin Nutr 2012;96(5):1032-41.

7. Wigle DT, Arbuckle TE, Turner MC, Berube A, Yang Q, Liu S, et al. Epidemiologic evidence of relationships between reproductive and child health outcomes and environmental chemical contaminants. J Toxicol Environ Health B Crit Rev 2008;11(5-6):373-517.

8. Brown RC, Barone S, Jr, Kimmel CA. Children's health risk assessment: incorporating a lifestage approach into the risk assessment process. Birth Defects Res B Dev Reprodu Toxicol 2008;83(6):511-21.

9. Magnus P, Irgens LM, Haug K, Nystad W, Skjaerven R, Stoltenberg C. Cohort profile: The Norwegian Mother and Child Cohort Study (MoBa). Int J Epidemiol 2006;35(5):1146-50.

10. Newby PK, Tucker KL. Empirically derived eating patterns using factor or cluster analysis: a review. Nutr Rev 2004;62(5):177-203.

11. Hu FB. Dietary pattern analysis: a new direction in nutritional epidemiology. Curr Opin Lipidol 2002;13(1):3-9.

12. Haugen M, Brantsæter AL, Alexander J, Meltzer HM. Dietary supplements contribute substantially to the total nutrient intake in pregnant Norwegian women. Ann Nutr Metab 2008;52(4):272-80.

13. Brantsæter AL, Abel MH, Haugen M, Meltzer HM. Risk of suboptimal iodine intake in pregnant Norwegian women. Nutrients 2013;5(2):424-40.

14. Torjusen H, Lieblein G, Naes T, Haugen M, Meltzer HM, Brantsæter AL. Food patterns and dietary quality associated with organic food consumption during pregnancy; data from a large cohort of pregnant women in Norway. BMC Public Health 2012;12:612.

15. Nilsen RM, Vollset SE, Monsen AL, Ulvik A, Haugen M, Meltzer HM, et al. Infant birth size is not associated with maternal intake and status of folate during the second trimester in Norwegian pregnant women. J Nutr 2010;140(3):572-9.

16. Sengpiel V, Elind E, Bacelis J, Nilsson S, Grove J, Myhre R, et al. Maternal caffeine intake during pregnancy is associated with birth weight but not with gestational length: results from a large prospective observational cohort study. BMC Medicine 2013;11:42.

17. Brantsæter AL, Birgisdottir BE, Meltzer HM, Kvalem HE, Alexander J, Magnus P, et al. Maternal seafood consumption and infant birth weight, length and head circumference in the Norwegian Mother and Child Cohort Study. Br J Nutr 2012;107(3):436-44.

18. Vejrup K, Brantsæter AL, Knutsen HK, Magnus P, Alexander J, Kvalem HE, et al. Prenatal mercury exposure and infant birth weight in the Norwegian Mother and Child Cohort Study. Public Health Nutr 2013:1-10.

19. Duarte-Salles T, von SH, Granum B, Gutzkow KB, Rydberg P, Tornqvist M, et al. Dietary Acrylamide Intake during Pregnancy and Fetal Growth - Results from the Norwegian Mother and Child Cohort study (MoBa). Environ Health Perspect 2013;121:374-9.

20. Duarte-Salles T, Mendez MA, Meltzer HM, Alexander J, Haugen M. Dietary benzo(a)pyrene intake during pregnancy and birth weight: associations modified by vitamin C intakes in the Norwegian Mother and Child Cohort Study (MoBa). Environ Int 2013;60:217-23.

21. Papadopoulou E, Caspersen IH, Kvalem HE, Knutsen HK, Duarte-Salles T, Alexander J, et al. Maternal dietary intake of dioxins and polychlorinated biphenyls and birth size in the Norwegian Mother and Child Cohort Study (MoBa). Environ Int 2013;60C:209-16.

22. Hillesund ER, Bere E, Haugen M, Overby NC. Development of a New Nordic Diet score and its association with gestational weight gain and fetal growth - a study performed in the Norwegian Mother and Child Cohort Study (MoBa). Public Health Nutr 2014:1-11.

23. von Ruesten A, Brantsaeter AL, Haugen M, Meltzer HM, Mehlig K, Winkvist A, et al. Adherence of pregnant women to Nordic dietary guidelines in relation to postpartum weight retention: results from the Norwegian Mother and Child Cohort Study. BMC Public Health 2014;14(1):75.

24. Brantsæter AL, Haugen M, Samuelsen SO, Torjusen H, Trogstad L, Alexander J, et al. A dietary pattern characterized by high intake of vegetables, fruits, and vegetable oils is associated with reduced risk of preeclampsia in nulliparous pregnant Norwegian women. J Nutr 2009;139(6):1162-8. 
25. Haugen M, Brantsæter AL, Trogstad L, Alexander J, Roth C, Magnus P, et al. Vitamin D supplementation and reduced risk of preeclampsia in nulliparous women. Epidemiology 2009;20(5):720-6.

26. Brantsæter AL, Myhre R, Haugen M, Myking S, Sengpiel V, Magnus P, et al. Intake of probiotic food and risk of preeclampsia in primiparous women: the Norwegian Mother and Child Cohort Study. Am J Epidemiol 2011;174(7):807-15.

27. Borgen I, Aamodt G, Harsem N, Haugen M, Meltzer HM, Brantsæter AL. Maternal sugar consumption and risk of preeclampsia in nulliparous Norwegian women. Eur J Clin Nutr 2012;66(8):920-5.

28. Haugen M, Meltzer HM, Brantsæter AL, Mikkelsen T, Osterdal ML, Alexander J, et al. Mediterranean-type diet and risk of preterm birth among women in the Norwegian Mother and Child Cohort Study (MoBa): a prospective cohort study. Acta Obstet Gynecol Scand 2008;87(3):319-24.

29. Myhre R, Brantsæter AL, Myking S, Gjessing HK, Sengpiel V, Meltzer HM, et al. Intake of probiotic food and risk of spontaneous preterm delivery. Am J Clin Nutr 2011;93(1):151-7.

30. Myhre R, Brantsæter AL, Myking S, Eggesbø M, Meltzer HM, Haugen M, et al. Intakes of garlic and dried fruits are associated with lower risk of spontaneous preterm delivery. J Nutr 2013;143(7):1100-8.

31. Englund-Ögge L, Brantsæter AL, Haugen M, Sengpiel V, Khatibi A, Myhre R, et al. Association between intake of artificially sweetened and sugar-sweetened beverages and preterm delivery: a large prospective cohort study. Am J Clin Nutr 2012;96(3):552-9.

32. Englund-Ögge L, Brantsaeter AL, Sengpiel V, Haugen M, Birgisdottir BE, Myhre R, et al. Maternal dietary patterns and preterm delivery: results from large prospective cohort study. BMJ 2014;348:g1446.

33. Sengpiel V, Bacelis J, Myhre R, Myking S, Pay AD, Haugen M, et al. Folic acid supplementation, dietary folate intake during pregnancy and risk for spontaneous preterm delivery: a prospective observational cohort study. BMC Pregnancy Childbirth 2014 [published 2013, retracted, corrected and republished 2014].

34. Størdal K, Haugen M, Brantsæter AL, Lundin KE, Stene LC. Association between maternal iron supplementation during pregnancy and risk of celiac disease in children. Clin Gastroenterol Hepatol 2014;12(4):62431.e1-2.

35. Stølevik SB, Nygaard UC, Namork E, Haugen M, Meltzer HM, Alexander J, et al. Prenatal exposure to polychlorinated biphenyls and dioxins from the maternal diet may be associated with immunosuppressive effects that persist into early childhood. Food Chem Toxicol 2013;51:165-72.

36. Bertelsen RJ, Brantsæter AL, Magnus MC, Haugen M, Myhre R, Jacobsson B, et al. Probiotic milk consumption in pregnancy and infancy and subsequent childhood allergic diseases. J Allergy Clin Immunol 2013;133(1):165-71.

37. Jacka FN, Ystrom E, Brantsaeter AL, Karevold E, Roth C, Haugen M, et al. Maternal and early postnatal nutrition and mental health of offspring by age 5 years: a prospective cohort study. J Am Acad Child Adolesc Psychiatry 2013;52(10):1038-47.

38. Brantsæter AL, Whitworth KW, Ydersbond TA, Haug LS, Haugen M, Knutsen HK, et al. Determinants of plasma concentrations of perfluoroalkyl substances in pregnant Norwegian women. Environ Int 2013;54:7484.

39. Whitworth KW, Haug LS, Baird DD, Becher G, Hoppin JA, Skjaerven R, et al. Perfluorinated compounds in relation to birth weight in the Norwegian Mother and Child Cohort Study. Am J Epidemiol 2012;175(12):1209-16.

40. Fleten C, Nystad W, Stigum H, Skjaerven R, Lawlor DA, Davey Smith G, et al. Parent-offspring body mass index associations in the Norwegian Mother and Child Cohort Study: a family-based approach to studying the role of the intrauterine environment in childhood adiposity. Am J Epidemiol 2012;176(2):83-92.

41. Chortatos A, Haugen M, Iversen PO, Vikanes A, Magnus P, Veierød MB. Nausea and vomiting in pregnancy: associations with maternal gestational diet and lifestyle factors in the Norwegian Mother and Child Cohort Study. BJOG 2013;120(13):1642-53.

42. Khatibi A, Brantsæter AL, Sengpiel V, Kacerovsky M, Magnus P, Morken NH, et al. Prepregnancy maternal body mass index and preterm delivery. Am J Obstet Gynecol 2012;207(3):212-7.

43. Meltzer HM, Brantsæter AL, Ydersbond TA, Alexander J, Haugen M. Methodological challenges when monitoring the diet of pregnant women in a large study: experiences from the Norwegian Mother and Child Cohort Study (MoBa). Matern Child Nutr 2008;4(1):14-27.

44. Lauritsen J. FoodCalc: http://www.ibt.ku.dk/jesper/foodcalc (accessed February 2005).

45. Rimestad AH, Borgejordet A, Vesterhus KN, Sygnestveit K, Løken EB, Trygg K, et al. Matvaretabellen [The Norwegian Food Composition Table]. Oslo: Norwegian Food Safety Authority; Norwegian Directorate of Health; Department of Nutrition, University of Oslo, 2006.

46. Brantsæter AL, Haugen M, Thomassen Y, Ellingsen DG, Ydersbond TA, Hagve TA, et al. Exploration of biomarkers for total fish intake in pregnant Norwegian women. Public Health Nutr 2010;13(1):54-62.

47. Brantsæter AL, Haugen M, Alexander J, Meltzer HM. Validity of a new food frequency questionnaire for pregnant women in the Norwegian Mother and Child Cohort Study (MoBa). Matern Child Nutr 2008;4(1):2843. 
48. Brantsæter AL, Haugen M, Julshamn K, Alexander J, Meltzer HM. Evaluation of urinary iodine excretion as a biomarker for intake of milk and dairy products in pregnant women in the Norwegian Mother and Child Cohort Study (MoBa). Eur J Clin Nutr 2009;63(3):347-54.

49. Brantsæter AL, Haugen M, Rasmussen SE, Alexander J, Samuelsen SO, Meltzer HM. Urine flavonoids and plasma carotenoids in the validation of fruit, vegetable and tea intake during pregnancy in the Norwegian Mother and Child Cohort Study (MoBa). Public Health Nutr 2007;10(8):838-47.

50. Brantsæter AL, Haugen M, Hagve TA, Aksnes L, Rasmussen SE, Julshamn K, et al. Self-reported dietary supplement use is confirmed by biological markers in the Norwegian Mother and Child Cohort Study (MoBa). Ann Nutr Metab 2007;51(2):146-54.

51. Barker DJ. The developmental origins of adult disease. Eur J Epidemiol 2003;18(8):733-6.

52. Risnes KR, Vatten LJ, Baker JL, Jameson K, Sovio U, Kajantie E, et al. Birthweight and mortality in adulthood: a systematic review and meta-analysis. Int J Epidemiol 2011;40:647-61.

53. Chiavaroli V, Marcovecchio ML, de Giorgis T, Diesse L, Chiarelli F, Mohn A. Progression of cardiometabolic risk factors in subjects born small and large for gestational age. PLoS One 2014;9(8):e104278.

54. Pedersen M, von Stedingk H, Botsivali M, Agramunt S, Alexander J, Brunborg G, et al. Birth weight, head circumference, and prenatal exposure to acrylamide from maternal diet: the European prospective motherchild study (NewGeneris). Environ Health Perspect 2012;120(12):1739-45.

55. Nehring I, Lehmann S, von Kries R. Gestational weight gain in accordance to the IOM/NRC criteria and the risk for childhood overweight: a meta-analysis. Pediatr Obes 2013;8(3):218-24.

56. Nehring I, Schmoll S, Beyerlein A, Hauner H, von Kries R. Gestational weight gain and long-term postpartum weight retention: a meta-analysis. Am J Clin Nutr 2011;94(5):1225-31.

57. Melzer K, Schutz Y. Pre-pregnancy and pregnancy predictors of obesity. Int J Obes 2010;34 Suppl 2:S44-52.

58. Linne Y, Dye L, Barkeling B, Rossner S. Weight development over time in parous women - the SPAWN study - 15 years follow-up. Int J Obes Relat Metab Disord 2003;27(12):1516-22.

59. Sibai B, Dekker G, Kupferminc M. Pre-eclampsia. Lancet 2005;365(9461):785-99.

60. Redman CW, Sargent IL. Immunology of pre-eclampsia. Am J Reprod Immunol 2010;63(6):534-43.

61. Bodnar LM, Catov JM, Simhan HN, Holick MF, Powers RW, Roberts JM. Maternal vitamin D deficiency increases the risk of preeclampsia. J Clin Endocrinol Metab 2007;92(9):3517-22.

62. Hypponen E. Vitamin D for the prevention of preeclampsia? A hypothesis. Nutr Rev 2005;63(7):225-32.

63. Lye HS, Kuan CY, Ewe JA, Fung WY, Liong MT. The improvement of hypertension by probiotics: effects on cholesterol, diabetes, renin, and phytoestrogens. Int J Mol Sci 2009;10(9):3755-75.

64. Wallace TD, Bradley S, Buckley ND, Green-Johnson JM. Interactions of lactic acid bacteria with human intestinal epithelial cells: effects on cytokine production. J Food Protect 2003;66(3):466-72.

65. Yeganegi M, Watson CS, Martins A, Kim SO, Reid G, Challis JR, et al. Effect of Lactobacillus rhamnosus GR-1 supernatant and fetal sex on lipopolysaccharide-induced cytokine and prostaglandin-regulating enzymes in human placental trophoblast cells: implications for treatment of bacterial vaginosis and prevention of preterm labor. Am J Obstet Gynecol 2009;200(5):532-8.

66. Boyd HA, Poulsen G, Wohlfahrt J, Murray JC, Feenstra B, Melbye M. Maternal contributions to preterm delivery. Am J Epidemiol 2009;170(11):1358-64.

67. Goldenberg RL, Culhane JF, Iams JD, Romero R. Epidemiology and causes of preterm birth. Lancet 2008;371(9606):75-84.

68. Boyle JD, Boyle EM. Born just a few weeks early: does it matter? Arch Dis Child Fetal Neonatal Ed 2013;98(1):F85-F8.

69. Khashu M, Narayanan M, Bhargava S, Osiovich H. Perinatal outcomes associated with preterm birth at 33 to 36 weeks' gestation: a population-based cohort study. Pediatrics 2009;123(1):109-13.

70. Saigal S, Doyle LW. An overview of mortality and sequelae of preterm birth from infancy to adulthood. Lancet 2008;371(9608):261-9.

71. Khoury J, Henriksen T, Christophersen B, Tonstad S. Effect of a cholesterol-lowering diet on maternal, cord, and neonatal lipids, and pregnancy outcome: a randomized clinical trial. Am J Obstet Gynecol 2005;193(4):1292-301.

72. AICR. Food, nutrition, physical activity, and the prevention of cancer: a global perspective, 2nd edn. Washington DC: World Cancer Research Fund, 2007.

73. Vergnaud AC, Romaguera D, Peeters PH, van Gils CH, Chan DS, Romieu I, et al. Adherence to the World Cancer Research Fund/American Institute for Cancer Research guidelines and risk of death in Europe: results from the European Prospective Investigation into Nutrition and Cancer cohort study1,4. Am J Clin Nutr 2013;97(5):1107-20.

74. Kostråd for å fremme folkehelsen og forebygge kroniske sykdommer. Metodologi og vitenskapelig kunnskapsgrunnlag. [In Norwegian]. Available online at http://helsedirektoratet.no/publikasjoner/kostrad-fora-fremme-folkehelsen-og-forebygge-kroniske-sykdommer/Publikasjoner/kostrad-for-a-fremme-folkehelsen2011.pdf. The Norwegian Directorate of Health, Oslo 2011. 
75. Mattilsynet. Kostholdsråd for gravide. [Dietary advice for pregnant women, in Norwegian]. Norwegian Food Safety Authority, Norwegian Directorate of Health, Norwegian Institute of Public Health. Available online at: http://www.matportalen.no/rad_til_spesielle_grupper/tema/gravide/.

76. Retningslinjer for svangerskapsomsorgen [National guidelines for antenatal care in Norway]. Oslo: Directorate for Health and Social Affairs, 2005.

77. Care Study Group. Maternal caffeine intake during pregnancy and risk of fetal growth restriction: a large prospective observational study. BMJ 2008;337:a2332.

78. Peck JD, Leviton A, Cowan LD. A review of the epidemiologic evidence concerning the reproductive health effects of caffeine consumption: a 2000-2009 update. Food Chem Toxicol 2010;48(10):2549-76.

79. Maslova E, Bhattacharya S, Lin SW, Michels KB. Caffeine consumption during pregnancy and risk of preterm birth: a meta-analysis. Am J Clin Nutr 2010;92(5):1120-32.

80. Liu RH. Health-promoting components of fruits and vegetables in the diet. Adv Nutr 2013;4(3):384s-92s.

81. Maslowski KM, Mackay CR. Diet, gut microbiota and immune responses. Nature Immunol 2011;12(1):5-9.

82. Cotillard A, Kennedy SP, Kong LC, Prifti E, Pons N, Le Chatelier E, et al. Dietary intervention impact on gut microbial gene richness. Nature 2013;500(7464):585-8.

83. Carvalho BM, Saad MJ. Influence of gut microbiota on subclinical inflammation and insulin resistance. Mediators Inflamm 2013;2013.

84. Flint HJ, Scott KP, Louis P, Duncan SH. The role of the gut microbiota in nutrition and health. Nature Reviews Gastroenterol Hepatol 2012;9(10):577-89.

85. Stout MJ, Conlon B, Landeau M, Lee I, Bower C, Zhao Q, et al. Identification of intracellular bacteria in the basal plate of the human placenta in term and preterm gestations. Am J Obstet Gynecol 2013;208(3):226.e1-7.

86. Aagaard K, Ma J, Antony KM, Ganu R, Petrosino J, Versalovic J. The placenta harbors a unique microbiome. Sci Transl Med 2014;6(237):237ra65.

87. Saito S, Shiozaki A, Nakashima A, Sakai M, Sasaki Y. The role of the immune system in preeclampsia. Mol Aspects Med 2007;28(2):192-209.

88. MacIntyre DA, Sykes L, Teoh TG, Bennett PR. Prevention of preterm labour via the modulation of inflammatory pathways. J Matern Fetal Neonatal Med 2012;25 Suppl 1:17-20.

89. Leventakou V, Roumeliotaki T, Martinez D, Barros H, Brantsaeter AL, Casas M, et al. Fish intake during pregnancy, fetal growth, and gestational length in 19 European birth cohort studies. Am J Clin Nutr 2014;99(3):506-16.

90. Pedersen M, Schoket B, Godschalk RW, Wright J, von Stedingk H, Tornqvist M, et al. Bulky DNA adducts in cord blood, maternal fruit-and-vegetable consumption, and birth weight in a European mother-child study (NewGeneris). Environ Health Perspect 2013;121(10):1200-6.

91. Palli D, Masala G, Vineis P, Garte S, Saieva C, Krogh V, et al. Biomarkers of dietary intake of micronutrients modulate DNA adduct levels in healthy adults. Carcinogenesis 2003;24(4):739-46.

92. Busby A, Abramsky L, Dolk H, Armstrong B. Preventing neural tube defects in Europe: population based study. BMJ 2005;330(7491):574-5.

93. Wilcox AJ, Lie RT, Solvoll K, Taylor J, McConnaughey DR, Abyholm F, et al. Folic acid supplements and risk of facial clefts: national population based case-control study. BMJ 2007;334(7591):464.

94. Fekete K, Berti C, Trovato M, Lohner S, Dullemeijer C, Souverein OW, et al. Effect of folate intake on health outcomes in pregnancy: a systematic review and meta-analysis on birth weight, placental weight and length of gestation. Nutr J 2012;11:75.

95. Olafsdottir AS, Thorsdottir I, Gunnarsdottir I, Thorgeirsdottir H, Steingrimsdottir L. Comparison of women's diet assessed by FFQs and 24-hour recalls with and without underreporters: associations with biomarkers. Ann Nutr Metab 2006;50(5):450-60.

96. Kristal AR, Peters U, Potter JD. Is it time to abandon the food frequency questionnaire? Cancer Epidemiol Biomarkers Prev 2005;14(12):2826-8.

97. Brantsæter AL, Haugen M, de Mul A, Bjellaas T, Becher G, van Klaveren J, et al. Exploration of different methods to assess dietary acrylamide exposure in pregnant women participating in the Norwegian Mother and Child Cohort Study (MoBa). Food Chem Toxicol 2008;46(8):2808-14.

98. Parr CL, Veierød MB, Laake P, Lund E, Hjartåker A. Test-retest reproducibility of a food frequency questionnaire (FFQ) and estimated effects on disease risk in the Norwegian Women and Cancer Study. Nutr J 2006; 5:4.

99. Nilsen RM, Vollset SE, Gjessing HK, Skjaerven R, Melve KK, Schreuder P, et al. Self-selection and bias in a large prospective pregnancy cohort in Norway. Paediatr Perinat Epidemiol 2009;23(6):597-608.

100. Nilsen RM, Suren P, Gunnes N, Alsaker ER, Bresnahan M, Hirtz D, et al. Analysis of self-selection bias in a population-based cohort study of autism spectrum disorders. Paediatr Perinat Epidemiol 2013;27(6):553-63. 